\title{
STABILIZATION/SOLIDIFICATION (S/S) OF Pb AND W CONTAMINATED SOILS USING TYPE I/II PORTLAND CEMENT, SILICA FUME CEMENT AND CEMENT KILN DUST
}

\author{
D.G. GRUBB $B^{1,2}$ \\ D.H. MOON ${ }^{1,3, *}$ \\ T. REILLY ${ }^{1}$ \\ M. CHRYSOCHOOU ${ }^{1,4}$ \\ D. DERMATAS ${ }^{1}$
}

\author{
${ }^{1}$ W.M. Keck Geoenvironmental Laboratory, \\ Center for Environmental Systems \\ Stevens Institute of Technology, Hoboken, NJ 07030, USA \\ ${ }^{2}$ Schnabel Engineering, LLC, 510 East Gay Street \\ West Chester, PA 19380, USA \\ ${ }^{3}$ Department of Environmental Engineering \\ Chosun University, Gwangju 501-759, South Korea \\ ${ }^{4}$ Civil \& Environmental Engineering \\ University of Connecticut, Storrs, CT 06269, USA
}

*to whom all correspondence should be addressed:

e-mail: dmoon10@hotmail.com
Received: 25/08/08

Accepted: 07/01/09

\section{ABSTRACT:}

Stabilization/solidification $(\mathrm{S} / \mathrm{S})$ processes were utilized to immobilize lead $(\mathrm{Pb})$ and tungsten (W) in contaminated soils, the inclusion of $\mathrm{W}$ motivated by the use of the new W-based ammunition. Artificially contaminated soils were prepared by mixing either kaolinite or montmorillonite with $10 \% \mathrm{~Pb}$ and $1 \% \mathrm{~W}$ (all percentages by dry weight). Type I/II Portland cement (PC), silica fume cement (SFC) and cement kiln dust (CKD) were used as S/S agents. The S/S agents were added at 5, 10 and $15 \%$ for a curing time of 1-, 7- and 28-days. The toxicity characteristic leaching procedure (TCLP) and synthetic precipitation leaching procedure (SPLP) were used to evaluate the effectiveness of the treatments. X-ray powder diffraction (XRPD) was used to investigate the crystalline mineral phases responsible for $\mathrm{Pb}$ and $\mathrm{W}$ immobilization. The TCLP results showed that regardless of clay type and stabilizing agents, the $\mathrm{Pb}$ concentrations decreased with increasing pozzolan content. PC and SFC exhibited similar performance depending on the particular sample (not consistent with soil type, dosage, and curing time). The most effective stabilizing agent on Pb leachability was PC despite SFC being silica-enriched which should have contributed to its greater immobilization of $\mathrm{Pb}$. TCLP-W was immobilized below $1 \mathrm{mg} \mathrm{I}^{-1}$ in every case. The most effective stabilizing agent on the SPLP-Pb leachability was CKD, consistently demonstrating among the lowest concentrations for each soil type due to $\mathrm{pH}$ control. PC and SFC exhibited similar performance depending on the particular sample (not consistent with soil type, dosage, and curing time). The $\mathrm{W}$ concentrations in SPLP leachate were very low in most samples indicating that $\mathrm{W}$ could be immobilized upon $\mathrm{S} / \mathrm{S}$ processes even though $\mathrm{W}$ solubility is very high at elevated $\mathrm{pH}$ conditions $\left(662.9 \mathrm{mg} \mathrm{l}^{-1}\right.$ at $\left.\mathrm{pH} 11\right)$, and would remain immobilized under SPLP exposure conditions. The XRPD results revealed that the formation of lead silicate $\left(\mathrm{Pb}_{4} \mathrm{SiO}_{6}\right)$, stolzite $\left(\mathrm{PbWO}_{4}\right)$ and lead tungsten oxide $\left(\mathrm{Pb}_{0.29} \mathrm{WO}_{3}\right)$ were strongly associated with the immobilization of $\mathrm{Pb}$ in the $\mathrm{S} / \mathrm{S}$ matrix.

\section{INTRODUCTION}

Many metals may occur in firing range soils due to the composition of shells, casings and penetrators. In recent years lead $(\mathrm{Pb})$ contamination in firing range soils has received much attention as an environmental concern (Cao et al., 2003; Dermatas et al., 2004c). According to the USGS (2002), firing ranges are considered one of the largest $\mathrm{Pb}$ contributors to the environment. It has been reported that there are more than 3,000 active Department of Defense (DoD) small arms firing ranges (SAFRs). The EPA estimated that in the late 1990's 
about 80,000 tons/year of $\mathrm{Pb}$ went to making bullets and shot (USEPA, 2005). Upon impact with the berm surface, bullet fragments and $\mathrm{Pb}$ particulates build up significantly with continued range operations. Previous $\mathrm{Pb}$ leachability studies showed that if proper management was not implemented, the $\mathrm{Pb}$ leachability may not satisfy the Toxicity Characteristic Leaching Procedure (TCLP) regulatory limit of $5 \mathrm{mg} \mathrm{l}^{-1}$ (Cao et al., 2003; Dermatas et al., 2006; Chrysochoou et al. 2007).

Tungsten (W) is a heavy metal that has been widely used in industrial and military applications due to its high melting/boiling points and density of $19.1 \mathrm{~g} \mathrm{~cm}^{-3}$ (USGS, 1998; Lassner and Schubert, 1999). This suggests that military, commercial and private shooting ranges may contain elevated concentrations of $\mathrm{W}$ due to the new $\mathrm{W}$-containing ammunition (Sadiq et al., 1992). However, regulations for $W$ have not yet been established in the USA (Strigul et al., 2005). For perspective, the Russian Federation regulates $\mathrm{W}$ in drinking water and fishing lakes to limits of $0.05 \mathrm{mg} \mathrm{l}^{-1}$ (Sanitary Rules and Norms of Russian Federation, 1996; and $0.0008 \mathrm{mg} \mathrm{I}^{-1}$ Order \#96, dd. 28 Apr 1999, State Russian Committee for Fishing, respectively).

Various branches of the US Government have estimated that W contamination in hunting grounds and firing ranges can be on the order of up to 50 and $5,000 \mathrm{mg} \mathrm{kg}^{-1}$ (AFRL; 1998; DOI, 1999; ITRC, 2003). Dermatas et al. (2004a) report aqueous equilibria data on a series of tungsten and tungsten alloys which were capable of producing concentrations on the order of 50 to $500 \mathrm{mg} \mathrm{l}^{-1} \mathrm{~W}$ over a broad range of $\mathrm{pH}$ (3 to 10). Sorption studies involving these same alloys were found to produce sorbed concentrations of $\mathrm{W}$ on clayey soils in the $1000 \mathrm{~s}$ of $\mathrm{mg}$ $\mathrm{kg}^{-1}$, with equilibrated $\mathrm{W}$ concentrations on the order of $30 \mathrm{mg} \mathrm{l}^{-1}$. In terms of W speciation in firing range soils, strong cues can be taken from Pourbaix (1974), who indicated that the main species of $\mathrm{W}$ in the $\mathrm{W}-\mathrm{H}_{2} \mathrm{O}$ system are $\mathrm{WO}_{3}(\mathrm{pH}<6.2)$ and $\mathrm{WO}_{4}{ }^{2-}(\mathrm{pH} \geq 6.2)$ over a broad range of oxidation conditions. Thus, unless provided in its mineral form (or alloyed), tungsten will likely predominate as tungstate in alkaline soils and pozzolanically stabilized systems. However, the environmental chemistry of tungsten under acidic conditions $(\mathrm{pH}<6.2)$ is very complex owing to the multiple oxidation states $(-2$ to +6$)$ possible with tungsten (Koutsospyros et al., 2006).

The use of high grade metals for bullet jacketing materials and penetrators creates the possibility for galvanic cells (corrosion) that accelerates the weathering of pure or alloyed metals in firing range soils. For example, Dermatas et al., (2004b) illustrated the accelerated lead oxidation by copper bullet jacketing materials which resulted in elevated aqueous concentrations of $\mathrm{Pb}$. Likewise, the use of iron (and possibly nickel) as an alloying metal enhanced the solubility of tungsten, but cobalt inhibited tungsten dissolution (Dermatas et al., 2004a). Accordingly, due to the possibility of galvanic effects and because $\mathrm{W}$ typically occurs as an oxyanion, the potential occurrence of $\mathrm{Pb}$ and $\mathrm{W}$ together in firing range soils make it necessary to investigate whether $\mathrm{Pb}$ and $\mathrm{W}$ will promote mutual solubilization. Moreover, since stabilization/solidification (S/S) is a leading method to stabilize $\mathrm{Pb}$ and other metals in firing range soils, there is considerable concern that $\mathrm{Pb}$ and $\mathrm{W}$ interactions may interfere with the respective immobilization of either metal during $S / S$ processes.

S/S techniques have been widely used for hazardous wastes since the early 1970s (Conner, 1990). Currently, S/S techniques are recognized by the EPA as the Best Demonstrated Available Technology (BDAT) for land disposal of most toxic elements (Shi and Spence, 2004; Singh and Pant, 2006). Moreover, S/S is one of the most common techniques applied at Superfund sites in the US (about 24\% of the sites being used between 1982 and 2002). S/S treatment to heavy metal contaminated soils utilizing pozzolanic reagents has shown to be a cost effective technique (Conner, 1990). By applying S/S techniques, contaminants can be converted to forms which are much less mobile, soluble, and toxic (Conner, 1990). Also, the contaminants can be incorporated into a monolithic solid with reduced surface area that physically encapsulates the contaminants yielding lower leachability results (Yukselen and Alpaslan, 2001; Dermatas et al., 2004d). 
Moon et al. (2006) observed that pozzolanic reaction products such as calcium silicate hydrate $(\mathrm{CSH})$ and calcium aluminate hydrate $(\mathrm{CAH})$ compounds appear to be the key crystalline phases responsible for strength gain in stabilized soils and reduced $\mathrm{Pb}$ leachability. Lead silicates were also important for $\mathrm{Pb}$ immobilization (Palomo and Palacios, 2003; Moon and Dermatas, 2006; Moon et al., 2006).

In this study, artificially $\mathrm{Pb}$ and $\mathrm{W}$ spiked clays were used to investigate $\mathrm{Pb}$ and $\mathrm{W}$ immobilization mechanisms. This work sought to determine if: 1) W would impact the prior trends observed for $\mathrm{Pb}$ immobilization resulting from $\mathrm{S} / \mathrm{S}$ treatment; and, 2) would the fate of $\mathrm{W}$ be analogous to other oxyanions such as arsenic, chromium (Jing et al., 2004) and selenium (Solem-Tishmack et al., 1995), which have been successfully stabilized in S/S media.

Two clays were chosen for this work, mainly due to the need to simplify, isolate and identify key trends in $\mathrm{Pb}$ and $\mathrm{W}$ speciation and leaching. The clays were chosen specifically based on consistency with Moon et al. (2006) who reported that the S/S of Pb-spiked montmorillonite (M) soils developed more strength and better immobilized $\mathrm{Pb}$ than kaolinite $(\mathrm{K})$ soils. This was chiefly attributed to the smaller grain size and reactivity of $M$ that may have enabled it to more readily dissolve and provide more soluble silica for the cement reactions, and thus, the formation of $\mathrm{CSH}$ compounds.

The cementing agents selected for this study included Type I/II Portland cement (PC), silica fume cement (SFC) and cement kiln dust (CKD) because they constitute a range of products available from the cement industry. PC was chosen because it represents one of the main industry choices for S/S work. SFC was chosen because it is marketed as being silica enriched $(\sim 8 \%)$ which should promote the formation of $\mathrm{CSH}$ compounds, whereas CKD exhibits comparable bulk chemistry (by X-ray Fluorescence; XRF) and greatly reduced costs versus both PC and SFC in select markets (>50\% savings). The use of CKD also supports sustainable practices. About 30 million tons of CKD are generated per year world wide (Dyer, 1999) with more than 4 million tons being generated in the USA (Sreekrishnavilasam et al., 2007). The cost associated with the disposal of CKD is high, stimulating the cement industry to develop practical applications for fresh CKD. Some researchers have studied S/S technologies using CKD to stabilize dredged material (Grubb et al., in press), expansive clays (Zaman et al., 1992) and with dune sand (Baghdadi, 1990), but there is very limited information in the literature dealing with the application of CKD to metals contaminated media.

\section{MATERIALS}

Kaolinite $(\mathrm{K})$ and montmorillonite $(\mathrm{M})$ were used to prepare artificially contaminated soils in order to investigate their physicochemical properties with respect to cation exchange capacity (CEC), surface area and ability to provide silica ( $\mathrm{Si}$ ) and alumina (AI) for the cement reactions. The $\mathrm{K}$ (KGa-2) and $\mathrm{M}(\mathrm{SWy}-2)$ clays used in this study were obtained from the Clay Minerals Society (Chantilly, VA) where the source designations are those provided by Chipera and Bish (2001). Select chemical and physical properties of the $\mathrm{K}$ and $\mathrm{M}$ soils are provided in Table 1. Each clay was spiked with $\mathrm{Pb}\left(\mathrm{NO}_{3}\right)_{2}$ (certified ACS grade, Fisher Scientific) at $10 \%$ by weight, or $100,000 \mathrm{mg} \mathrm{kg}^{-1}$. W was added at $1 \mathrm{wt} \%$ (<10 $\mu \mathrm{m}$ powder, $>99.99 \%$ purity, SIGMA-ALDRICH, St. Louis, MO) or $10,000 \mathrm{mg} \mathrm{kg}^{-1}$. After being thoroughly homogenized, the samples were placed in sealed 1-I high-density polyethylene (HDPE) containers and were left to mellow for a period of 30 days. The mellowing water contents of the $\mathrm{Pb}$ and $\mathrm{Pb}-\mathrm{W}$ spiked media were $20 \%$.

The PC, SFC and CKD used in this study were provided by LaFarge North America, (Whitehall, PA). A summary of the bulk chemistry (by $x$-ray fluorescence, XRF) of the stabilizing agents (provided by the supplier) is presented in Table 1.

After the mellowing period was complete (30 days), the soils were mixed with PC, SFC and CKD at dosages of 5,10 and $15 \mathrm{wt} \%$ (expressed as $\mathrm{g}$ stabilizing agent $100^{-1} \mathrm{~g}^{-1}$ dry soil). Specifically, 100 grams of each soil placed in a stainless steel mixing bowl and were manually 
homogenized with the respective dose of each stabilizing agent. Water was added at the $10 \%$ level based on total sample weight. Nine subsamples were prepared for each soil. After mixing, the amended soils were stored in sealed 125-ml HDPE bottles at room temperature and cured for 1-, 7- and 28-days.

Table 1. Major oxide chemistry for Montmorillonite, Kaolinite, Type I/II Portland Cement, Silica Fume Cement and Cement Kiln Dust

\begin{tabular}{|c|c|c|c|c|c|}
\hline Parameter & $\begin{array}{c}M \\
\text { (wt } \%)\end{array}$ & $\begin{array}{c}\mathrm{K} \\
\text { (wt } \%)\end{array}$ & $\begin{array}{c}\text { PC } \\
\text { (wt } \%)\end{array}$ & $\begin{array}{c}\text { SFC } \\
\text { (wt \%) }\end{array}$ & $\begin{array}{c}\text { CKD } \\
\text { (wt \%) }\end{array}$ \\
\hline Silicon Dioxide $\left(\mathrm{SiO}_{2}\right)$ & 62.90 & 43.90 & 20.40 & 24.20 & 16.10 \\
\hline Aluminum Oxide $\left(\mathrm{Al}_{2} \mathrm{O}_{3}\right)$ & 19.60 & 38.50 & 5.10 & 5.30 & 4.56 \\
\hline Iron Oxide $\left(\mathrm{Fe}_{2} \mathrm{O}_{3}\right)$ & 3.35 & 0.98 & 3.20 & 2.60 & 2.28 \\
\hline Calcium Oxide (CaO) & 1.68 & 0.20 & 62.50 & 56.50 & 46.48 \\
\hline Sodium Oxide $\left(\mathrm{Na}_{2} \mathrm{O}\right)$ & 1.53 & & & & 0.60 \\
\hline Potassium Oxide $\left(\mathrm{K}_{2} \mathrm{O}\right)$ & 0.50 & 0.10 & & & 3.01 \\
\hline Magnesium Oxide (MgO) & 3.05 & 0.03 & 3.80 & 2.30 & 2.79 \\
\hline Sulfur Trioxide $\left(\mathrm{SO}_{3}\right)$ & & & 2.80 & 4.10 & 8.16 \\
\hline Titanium Dioxide $\left(\mathrm{TiO}_{2}\right)$ & 0.09 & 2.08 & & & \\
\hline Moisture Content & & & & & 0.30 \\
\hline Loss On Ignition (LOI) & 1.59 & 12.60 & 1.02 & 2.10 & 16.03 \\
\hline Surface area $\left(\mathrm{m}^{2} / \mathrm{g}\right)$ & 760.00 & 66.00 & & & \\
\hline pH (L:S of 1:1) & 7.00 & $4.0-6.5$ & 12.24 & 12.45 & 12.73 \\
\hline pH (L:S of 20:1) & & & 11.25 & 11.58 & 12.14 \\
\hline CEC (meq/100g) & 80.00 & $4.5-5.5$ & & & \\
\hline \multicolumn{6}{|c|}{$\begin{array}{l}\text { Note: M and K data from Clay Minerals Society. Average CKD internal QA data for } 8 \text { data sets from 2/4/05 to 12/6/05 provided by Resource Material } \\
\text { Testing, Inc - Murphy, NC. Average PC Internal QA data for } 3 \text { data sets from 12/05 to 2/06 and SFC Internal QA data for 3/06 provided by Lafarge } \\
\text { North America - Northeast Region. }\end{array}$} \\
\hline
\end{tabular}

The sample nomenclature used in this study reflects five parameters: 1) clay type; 2) contaminants; 3) pozzolan; 4) pozzolan dose; and, 5) curing time. The two soils were montmorillonite $(\mathrm{M})$ and kaolinite $(\mathrm{K})$. Lead and tungsten are denoted as $\mathrm{P}$ and $\mathrm{W}$, respectively. PC, SFC and CKD are denoted as $\mathrm{C}, \mathrm{F}$ and $\mathrm{K}$, respectively. The curing time in days is indicated after the hyphen. An example ID breakdown for sample KPWF15-28 is as follows: K: kaolinite; PW: lead- and tungsten-spiked; F: treated with SFC; 15: 15 wt\% treatment; 28: cured for 28 days.

\section{METHODS}

\subsection{Totals Analysis}

For mass balance purposes and to aid in the mineralogical analyses, each untreated sample (control) was analyzed using USEPA SW846 Method 6010B/3051A (Test America, TN) for total $\mathrm{Pb}, \mathrm{W}$ and other major element concentrations. $\mathrm{Pb}$ and $\mathrm{W}$ doses of $100,000 \mathrm{mg} \mathrm{kg}^{-1}(10$ wt\%) and $10,000 \mathrm{mg} \mathrm{kg}^{-1}(1 \mathrm{wt} \%)$, respectively, were also applied to all soils. The results are shown in Table 2. The recovered $\mathrm{Pb}$ concentrations ranged from a low of $9,640 \mathrm{mg} \mathrm{kg}^{-1}$ $(9.64 \%)$ to a high of $30,600 \mathrm{mg} \mathrm{kg}^{-1}(30.6 \%)$, in samples KPW and MP, respectively. The highest W concentration was $340 \mathrm{mg} \mathrm{kg}^{-1}(0.034 \mathrm{wt} \%)$ from sample MPW, versus the theoretical $10,000 \mathrm{mg} \mathrm{kg}^{-1}$ (1 wt\%). Clearly, the low measured $\mathrm{Pb}$ and $\mathrm{W}$ concentrations using conventional protocols strongly suggested analytical problems related to: homogenizing samples, sample variability, potential limitations and/or matrix interferences during the extraction procedures. Therefore, a new methodology to analyze accurate total $\mathrm{Pb}$ and $\mathrm{W}$ concentrations was sought. 
Table 2. Environmental Parameters for Controls

\begin{tabular}{|c|c|c|c|c|}
\hline Parameter & MP & $\mathbf{K P}$ & MPW & KPW \\
\hline pH & 5.10 & 3.48 & 5.20 & 3.60 \\
\hline CEC & 25 & & 22 & \\
\hline Total Carbon & 1,340 & & 1,450 & \\
\hline Aluminum (Al) & 1,410 & 980 & 1,230 & 752 \\
\hline \multicolumn{5}{|l|}{ Antimony (Sb) } \\
\hline Arsenic (As) & 2 & & 1 & \\
\hline Barium (Ba) & 20 & 2 & 19 & \\
\hline \multicolumn{5}{|l|}{ Beryllium (Be) } \\
\hline \multicolumn{5}{|l|}{ Cadmium (Cd) } \\
\hline Calcium (Ca) & 5,600 & 43 & 5,530 & 56 \\
\hline \multicolumn{5}{|l|}{ Chloride (Cl) } \\
\hline Chromium (Cr) & & & & 1 \\
\hline \multicolumn{5}{|l|}{ Cobalt (Co) } \\
\hline \multicolumn{5}{|l|}{ Copper (Cu) } \\
\hline Iron (Fe) & 1,820 & 729 & 1,740 & 499 \\
\hline Lead (Pb) & 30,600 & 13,900 & 22,400 & 9,640 \\
\hline Magnesium (Mg) & 1,580 & 17 & 1,550 & 22 \\
\hline Manganese (Mn) & 89 & & 86 & 1 \\
\hline \multicolumn{5}{|l|}{ Nickel (Ni) } \\
\hline Potassium (K) & 369 & & 409 & \\
\hline Selenium (Se) & & & 5 & \\
\hline \multicolumn{5}{|l|}{ Silver (Ag) } \\
\hline Sodium (Na) & 4,500 & & 4,390 & \\
\hline \multicolumn{5}{|l|}{ Sulfate $\left(\mathrm{SO}_{4}\right)$} \\
\hline Tungsten (W) & & & 340 & 140 \\
\hline Vanadium (V) & & 17 & & 11 \\
\hline Zinc (Zn) & 30 & & 30 & \\
\hline \multicolumn{5}{|l|}{ Notes: } \\
\hline \multicolumn{5}{|c|}{ 1. All data in milligrams per liter (mg/kg) unless otherwise noted. } \\
\hline \multicolumn{5}{|c|}{ 2. pH measured at a liquid to solid ratio of 1:1 (SW846 9054C). } \\
\hline \multicolumn{5}{|c|}{ 3. CEC, Cation Exchange Capacity, in meq/100 grams (SW 846 9056). } \\
\hline \multicolumn{5}{|c|}{ 4. Total carbon analyzed in accordance SW846 9060M. } \\
\hline \multicolumn{5}{|c|}{ 5. Chloride and Sulfate analyzed in accordance with SW846 9056.} \\
\hline \multicolumn{5}{|c|}{ 6. All cations analyzed in accordance with SW846 6010B/3051A. } \\
\hline
\end{tabular}

\subsection{Revised Total $\mathrm{Pb}$ and $\mathrm{W}$ Analyses}

$\mathrm{Pb}$ analyses of the control samples and $\mathrm{Pb}-\mathrm{W}$ spiked soils were revised to follow EPA Method SW846 6010B/3050B for ICP-AES. The results of averaged duplicate samples are presented in Table 3. $\mathrm{Pb}$ recovery increased to a minimum of $90 \%$ (Table 3 ) using the revised (extraction) procedure. Extensive studies performed by Betancur (2007) determined that $100 \%$ recovery of metallic W powder was achievable by modifying the U.S. Occupational Safety and Health Administration (OSHA) Method ID-213; "ICP analysis of Tungsten and Cobalt in Workplace Atmospheres." The procedure was amended by adding $2 \mathrm{ml}$ of $\mathrm{H}_{2} \mathrm{O}_{2}$ after Step 8 in Section 3.5.3 of the ID-213 procedure (OSHA, 1994). In essence, $\mathrm{H}_{2} \mathrm{O}_{2}$ was added to a series of acid and phosphate extraction fluids to promote tungsten solubility and extraction. Also, a watch glass was used to cover the samples on the hot plate to promote refluxing. The results were significantly improved over Method SW846 6010B/3051A, as summarized in Table 3. Approximately $7,338 \mathrm{mg} \mathrm{kg}^{-1}(73.4 \%) \mathrm{W}$ was recovered from sample MPW, whereas W was previously detected at a concentration of $340 \mathrm{mg} \mathrm{kg}^{-1}(0.34 \%)$ (Table 2). The revised procedure proved equally successful for sample KPW, improving $W$ recovery to $7,236 \mathrm{mg} \mathrm{kg}^{-1}(72.4 \%)$. 
Table 3. $\mathrm{pH}$, Totals, TCLP and SPLP results for $\mathrm{Pb}$ and $\mathrm{W}$ from Control Samples

\begin{tabular}{cccccccccc}
\hline Sample & $\begin{array}{c}\text { Initial } \\
\mathbf{p H}\end{array}$ & $\begin{array}{c}\text { Total } \\
\mathbf{P b}\end{array}$ & Total $\mathbf{W}$ & $\begin{array}{c}\text { TCLP } \\
\mathbf{p H}\end{array}$ & $\begin{array}{c}\text { TCLP } \\
\mathbf{P b}\end{array}$ & $\begin{array}{c}\text { TCLP } \\
\mathbf{W}\end{array}$ & $\begin{array}{c}\text { SPLP } \\
\mathbf{p H}\end{array}$ & $\begin{array}{c}\text { SPLP } \\
\mathbf{P b}\end{array}$ & $\begin{array}{c}\text { SPLP } \\
\mathbf{W}\end{array}$ \\
\hline $\mathbf{M}$ & 7.57 & - & - & - & - & - & - & - & - \\
\hline MP & 5.13 & 90,404 & - & 4.93 & 2,786 & - & 5.18 & 994 & - \\
\hline MPW & 5.06 & 93,288 & 7,338 & 4.87 & 2,669 & 0.01 & 5.04 & 733 & 0.02 \\
\hline $\mathbf{K}$ & 3.72 & - & - & - & - & - & - & - & - \\
\hline KP & 3.13 & 97,778 & - & 4.56 & 4,214 & - & 3.85 & 4,197 & - \\
\hline KPW & 2.86 & 95,862 & 7,236 & 4.56 & 4,088 & 0.01 & 3.62 & 4,647 & 0.02 \\
\hline
\end{tabular}

Concentrations reported in $\mathrm{mg} \mathrm{kg}^{-1}$; Initial $\mathrm{pH}$ recorded at L:S ratio of 2:1; TCLP and SPLP pH recorded at L:S ratio of 20:1.

\subsection{TCLP and SPLP tests}

The toxicity characteristic leaching procedure (TCLP) and synthetic precipitation leaching procedure (SPLP) were used to evaluate the effectiveness of treatments for various curing times. The TCLP was performed in accordance with EPA Method 1311 (USEPA, 1992) to evaluate the leachability of $\mathrm{Pb}$ and $\mathrm{W}$ from the stabilized samples. All samples were passed through a No. 10 sieve $(2 \mathrm{~mm})$. The TCLP procedure was modified by taking 2-g of sample (instead of $100 \mathrm{~g}$ ) due to the small quantity of samples. Specifically, 2-g soil was placed in 40$\mathrm{mL}$ high-density polyethylene (HDPE) bottles and mixed with one of two leaching fluids. All control samples were extracted with a $\left(\sim 7 \times 10^{-5} \mathrm{M}\right)$ glacial $\mathrm{CH}_{3} \mathrm{CH}_{2} \mathrm{COOH}$ solution with $(\sim 1.61$ $\left.\times 10^{-3} \mathrm{M}\right) \mathrm{NaOH}(\mathrm{pH}=4.93 \pm 0.05)$. All treatments were extracted with dilute $\left(\sim 7 \times 10^{-5} \mathrm{M}\right)$ glacial $\mathrm{CH}_{3} \mathrm{CH}_{2} \mathrm{COOH}$ solution $(\mathrm{pH}=2.88 \pm 0.05)$. The leaching fluids were selected based on the $\mathrm{pH}$ and buffering capacity of the soil as specified in the procedure. All samples were tumbled at $30 \mathrm{rpm}$ in a TCLP tumbler (Millipore) for 72 hours to promote equilibrium conditions. pH (Denver Instrument UB-10) was measured and the leachate was filtered through a $0.45-\mu \mathrm{m}$ pore-size membrane filter prior to ICP analysis. The concentrations of soluble $\mathrm{Pb}$ and $\mathrm{W}$ were analyzed using an inductively coupled plasma optical emission spectrometer (ICP-OES) (Thermo Varian Vista-MPX, Varian, Palo Alto, CA). The instrument detection limit (IDL) was determined to be $0.013 \mathrm{mg} \mathrm{I}^{-1}$. When possible, sample analyses were performed in duplicate and averaged values were reported. For QA/QC purposes, two different quality control standards along with the method of standard addition (spiking) were used every 10 samples. The SPLP was performed in accordance with EPA Method 1312 (USEPA, 1992). The SPLP leaching fluid was a $60 / 40 \mathrm{w} / \mathrm{w}$ mixture of sulfuric and nitric acids (or a suitable dilution) with a $\mathrm{pH}$ of $4.20 \pm 0.05$. All controls and treatments used the same extraction fluid. All other procedures were identical to the TCLP test.

\subsection{X-ray powder diffraction (XRPD) analyses}

$\mathrm{X}$-ray powder diffraction (XRPD) was used to investigate the crystalline mineral phases responsible for $\mathrm{Pb}$ and $\mathrm{W}$ immobilization in the spiked soils and soil-cement slurries. Select XRPD analyses were conducted on the M, K, PC, SFC and CKD in order to obtain their mineralogical characteristics either qualitatively or quantitatively. This included the controls and $\mathrm{Pb}$ and $\mathrm{W}$-spiked $\mathrm{M}$ and $\mathrm{K}$ samples and each treatment at the 5 and $15 \mathrm{wt} \%$ dosing level.

Representative samples were air dried for 24 hours and then were pulverized to pass through a US standard \#400 sieve $(38 \mu \mathrm{m})$ to allow for quantitative analysis. The resulting powder was mixed with either $20 \%$ or $50 \% \mathrm{w} / \mathrm{w}$ of internal standard ( $\alpha$-corundum, $\mathrm{Al}_{2} \mathrm{O}_{3}$ ) (Sawyer, Lot. No. C04-AO-41). Step-scanned X-ray diffraction data were collected with a Rigaku DXR 3000 computer-automated diffractometer using Bragg-Brentano geometry. The XRPD analyses were conducted at $40 \mathrm{kV}$ and $40 \mathrm{~mA}$ using a diffracted beam graphite-monochromator with $\mathrm{Cu}$ radiation. The data was collected in the range of $5^{\circ}$ to $65^{\circ} 2 \theta$ with a step size of $0.02^{\circ}$ and a count time of 3 seconds per step. XRPD patterns were qualitatively analyzed using Jade software version 7.1 (MDI, 2005) and reference to the patterns of the International Centre for Diffraction Data database (ICDD, 2002). The Whole Pattern Fitting function of Jade, which is based on the Rietveld method (Rietveld, 1969), was applied with Inorganic Crystal Structure Database in order to quantify the presence of the crystalline mineral phases (ICSD, 2006). 


\section{RESULTS AND DISCUSSION}

\subsection{Mineralogy of soils and pozzolans}

In order to characterize the clays, Chipera and Bish (2001) performed an extensive analysis of the "pure" clays available from the Clay Minerals Society, e.g., the source of clays for this study. The XRF results summarized in Table 1 generally agree with their findings.

The minerals identified in M soil were quartz and silicon oxide by XRD. Chipera and Bish's (2001) quantitative analysis found this particular clay to be comprised of approximately $75 \%$ smectite, $8 \%$ quartz, $16 \%$ feldspar and $1 \%$ undetermined (gypsum plus mica and/or illite plus kaolinite and/or chlorite).

The diffractogram for the $\mathrm{K}$ soil consisted of only kaolinite. Chipera and Bish (2001) reported this kaolinite to be composed of roughly $96 \%$ kaolinite, $3 \%$ anatase and $1 \%$ undetermined (crandallite plus mica and/or illite). Though not accounted for in our XRPD patterns, anatase $\left(\mathrm{TiO}_{2}\right)$ may be potentially accounted for via the major element chemistry, as shown in Table 1 (2.08 wt\%). Chipera and Bish (2001) believed crandallite to be present in their samples but were unable to positively identify it based on the limited number of discreet reflections in the patterns.

The total chemistry and XRD quantification results for the pozzolans are presented in Tables 1 and 4 , respectively. Note that the silica fume $(\sim 8 \%)$ is directly reflected in the amorphous content differences between PC and SFC (Table 4). CKD, on the other hand, has a substantial portion of its content dominated by calcite which is unreactive but provides alkalinity. These mineralogical differences are therefore expected to affect metals immobilization, and that the pozzolanic reaction products $\mathrm{CSH}$ and $\mathrm{CAH}$ would be formed readily in the PC and SFC treatments, at a minimum.

Table 4. Composition of PC, SFC and CKD by XRPD and Reitveld Quantitative Analysis

$$
\text { (RQA). }
$$

\begin{tabular}{|c|c|c|c|c|}
\hline Parameter & Formula & PC (\%) & SFC (\%) & CKD (\%) \\
\hline Belite & $\mathrm{Ca}_{2} \mathrm{SiO}_{4}$ & 140 & 6,8 & 3,5 \\
\hline Alite & $\mathrm{Ca}_{3} \mathrm{SiO}_{5}$ & 44,0 & 27,0 & \\
\hline Tricalcium aluminate & $\mathrm{Ca}_{3} \mathrm{Al}_{2} \mathrm{O}_{6}$ & 7,5 & 7,4 & \\
\hline Brownmillerite & $\mathrm{Ca}_{2}(\mathrm{Al}, \mathrm{Fe})_{2} \mathrm{O}_{5}$ & 5,2 & 3,3 & \\
\hline Periclase & $\mathrm{MgO}$ & 1,7 & 1,4 & \\
\hline Gypsum & $\mathrm{CaSO}_{4} * 2 \mathrm{H}_{2} \mathrm{O}$ & 1,2 & 4,4 & \\
\hline Calcite & $\mathrm{CaCO}_{3}$ & & & 27,7 \\
\hline Lime & $\mathrm{CaO}$ & & & 4,4 \\
\hline Dolomite & $\mathrm{Ca}, \mathrm{Mg}\left(\mathrm{CO}_{3}\right)_{2}$ & & & 3,1 \\
\hline Quartz & $\mathrm{SiO}_{2}$ & & & 5,4 \\
\hline Silicon & $\mathrm{Si}$ & & & 0,5 \\
\hline Gehlenite & $\mathrm{Ca}_{2} \mathrm{Al}_{2} \mathrm{SiO}_{7}$ & & & 5,7 \\
\hline Anhydrite & $\mathrm{CaSO}_{4}$ & & & 3,0 \\
\hline $\mathrm{CAH}$ & & & & 0,9 \\
\hline Amorphous & & 40,4 & 49,7 & 45,9 \\
\hline
\end{tabular}

\subsection{TCLP vs. pH solubility trends}

The TCLP-Pb results for the 7- and 28-day cured samples for $\mathrm{Pb}$ and $\mathrm{Pb}-\mathrm{W}$ spiked soils are shown respectively in Figures 1 and 2. The TCLP data with respect to sample K5F25L10 (F = Class $C$ fly ash; $L=$ quicklime) and the $P b$ solubility curve presented by Dermatas and Meng (2003) are also shown for reference purposes. As observed in Dermatas and Meng (2003), the experimental data for the treatments can exceed the solubility line (usually less than 10x) due to the complexity of the systems. The experimentally determined $\mathrm{Pb}$ solubility curve illustrates that $\mathrm{Pb}$ achieves its minimum solubilities at mid-range to alkaline $(7-10) \mathrm{pH}$ levels, for a $\mathrm{Pb}$ spiking rate of $0.7 \mathrm{wt} \%$, or $7,000 \mathrm{mg} \mathrm{kg}^{-1}$ (Dermatas and Meng, 2003). At a pH<9, $\mathrm{Pb}$ solubility is somewhat influenced by surface adsorption but is mainly solubility controlled. Non-detects were plotted as the instrument detection limit (IDL) of $0.013 \mathrm{mg} \mathrm{l}^{-1}$. Missing and/or compromised samples were not plotted. 
Table 5. Compounds identified in soil treatments using Jade and the ICDD database

\begin{tabular}{|c|c|c|c|c|c|c|}
\hline Symbol & Compound & Formula & ICDD ID & Primary Peak & Secondary Peak & Tertiary Peak \\
\hline $\mathrm{AlO}$ & Aluminum Oxide & $\mathrm{Al}_{2} \mathrm{O}_{3}$ & $01-078-2427$ & 35.155 & 43.358 & 57.508 \\
\hline B & Brownmillerite & $\mathrm{Ca}_{2}\left(\mathrm{Al}, \mathrm{Fe}^{3+}\right)_{2} \mathrm{O}_{5}$ & $00-030-0226$ & 33.876 & 12.198 & 50.229 \\
\hline $\mathrm{C}$ & Cerussite & $\mathrm{PbCO}_{3}$ & $00-047-1734$ & 24.78 & 25.428 & 36.041 \\
\hline $\mathrm{Ca}$ & Calcite & $\mathrm{CaCO}_{3}$ & 01-083-0578 & 29.41 & 48.52 & 47.526 \\
\hline $\mathrm{CAO}$ & Calcium Aluminum Oxide & CaAlO & $00-033-0251$ & 33.229 & 32.915 & 33.015 \\
\hline Co & Corundum & $\mathrm{Al}_{2} \mathrm{O}_{3}$ & $97-002-4723$ & 43.357 & 57.505 & 35.154 \\
\hline G & Gypsum & $\mathrm{CaSO}_{4} \cdot 2 \mathrm{H}_{2} \mathrm{O}$ & 00-033-0311 & 11.588 & 20.722 & 29.111 \\
\hline $\mathrm{Ha}$ & Hatrurite & $\mathrm{Ca}_{3}\left(\mathrm{SiO}_{4}\right) \mathrm{O}$ & $97-007-4524$ & 24.111 & 23.69 & 25.351 \\
\hline $\mathrm{HC}$ & Hydrocerussite & $\left(\mathrm{Pb}_{3}\left(\mathrm{CO}_{3}\right)_{2} \mathrm{OH}\right)$ & 00-013-0131 & 34.156 & 24.641 & 27.081 \\
\hline $\mathrm{K}$ & Kaolinite & $\mathrm{Al}_{2} \mathrm{Si}_{2} \mathrm{O}_{5}(\mathrm{OH})_{4}$ & $99-000-1856$ & 12.457 & 24.992 & 20.119 \\
\hline $\mathrm{L}$ & Larnite & $\mathrm{Ca}_{2}\left(\mathrm{SiO}_{4}\right)$ & $97-005-9914$ & 32.054 & 32.609 & 32.171 \\
\hline $\mathrm{Li}$ & Lime & $\mathrm{CaO}$ & $00-037-1497$ & 37.347 & 53.856 & 32.204 \\
\hline M & Montmorillonite & $(\mathrm{Na}, \mathrm{Ca}) \mathrm{O}_{3}(\mathrm{Al}, \mathrm{Mg})_{2} \mathrm{Si}_{4} \mathrm{O}_{10}(\mathrm{OH})_{2} \cdot \mathrm{H}_{2} \mathrm{O}$ & 00-029-1498 & 6.494 & 19.891 & 35.023 \\
\hline $\mathrm{P}$ & Periclase & $\mathrm{MgO}$ & 00-045-0946 & 42.917 & 62.303 & 109.764 \\
\hline Po & Portlandite & $\mathrm{Ca}(\mathrm{OH})_{2}$ & $00-004-0733$ & 34.089 & 18.089 & 47.124 \\
\hline $\mathrm{PbNO}$ & Lead Nitrate & $\mathrm{Pb}\left(\mathrm{NO}_{3}\right)_{2}$ & $00-036-1462$ & 19.564 & 37.943 & 39.698 \\
\hline $\mathrm{PbO}$ & Lead Oxide & $\mathrm{PbO}$ & $97-004-6678$ & 28.628 & 54.769 & 31.836 \\
\hline $\mathrm{PbSi}$ & Lead Silicate & $\mathrm{Pb}_{4} \mathrm{SiO}_{6}$ & 00-037-0203 & 31.08 & 28.545 & 9.138 \\
\hline $\mathrm{PbW}$ & Stolzite & $\mathrm{PbWO}_{4}$ & $97-003-9847$ & 27.451 & 55.38 & 44.824 \\
\hline $\mathrm{PbWO}$ & Lead Tungsten Oxide & $\mathrm{Pb}_{0.29} \mathrm{WO}_{3}$ & $01-087-0282$ & 27.792 & 36.708 & 23.502 \\
\hline Q & Quartz & $\mathrm{SiO}_{2}$ & $99-000-3084$ & 26.644 & 20.86 & 36.542 \\
\hline $\mathrm{R}$ & Riversideite & $\mathrm{Ca}_{5} \mathrm{Si}_{6} \mathrm{O}_{16}(\mathrm{OH})_{2} \cdot 2 \mathrm{H}_{2} \mathrm{O}$ & $99-00-3177$ & 29.615 & 24.78 & 28.309 \\
\hline $\mathrm{SiO}$ & Silicon Oxide & $\mathrm{SiO}$ & 01-082-1570 & 20.874 & 37.731 & 27.639 \\
\hline$W$ & Tungsten & $W$ & $01-089-3659$ & 40.266 & 73.192 & 58.257 \\
\hline WSi & Tungsten Silicide & $\mathrm{WSi}_{2}$ & 01-081-0168 & 25.952 & 41.343 & 47.868 \\
\hline
\end{tabular}

Note: Peak location given in 2-Theta 


\section{$\mathrm{Pb}$ Spiked Soil}

The 5,10 and $15 \%$ dosing results were generally clustered by dose with respect to $\mathrm{pH}$ as shown in Figures $1 \mathrm{~A}$ and $2 \mathrm{~A}$, with pozzolans performing similarly for the most part (usually $\mathrm{Pb}$ concentration within same order of magnitude). The $\mathrm{K}$ soils, on average, were slightly more alkaline than the $\mathrm{M}$ soils, which was unexpected. The pure pozzolans had somewhat varying $\mathrm{pH}$ values (Table 1 ) and buffering capacity which affected the $\mathrm{Pb}$ speciation and solubility. Raw PC had the lowest $\mathrm{pH}$ while the CKD had the highest $\mathrm{pH}$. The post tumbling pHs, however, were generally the opposite, as $\mathrm{PC}$ usually provided the greatest $\mathrm{pH}$ buffering per dose. Increasing pozzolan doses likewise increases the available Si and Al to potentially form $\mathrm{CSH}$ and $\mathrm{CAH}$ compounds.
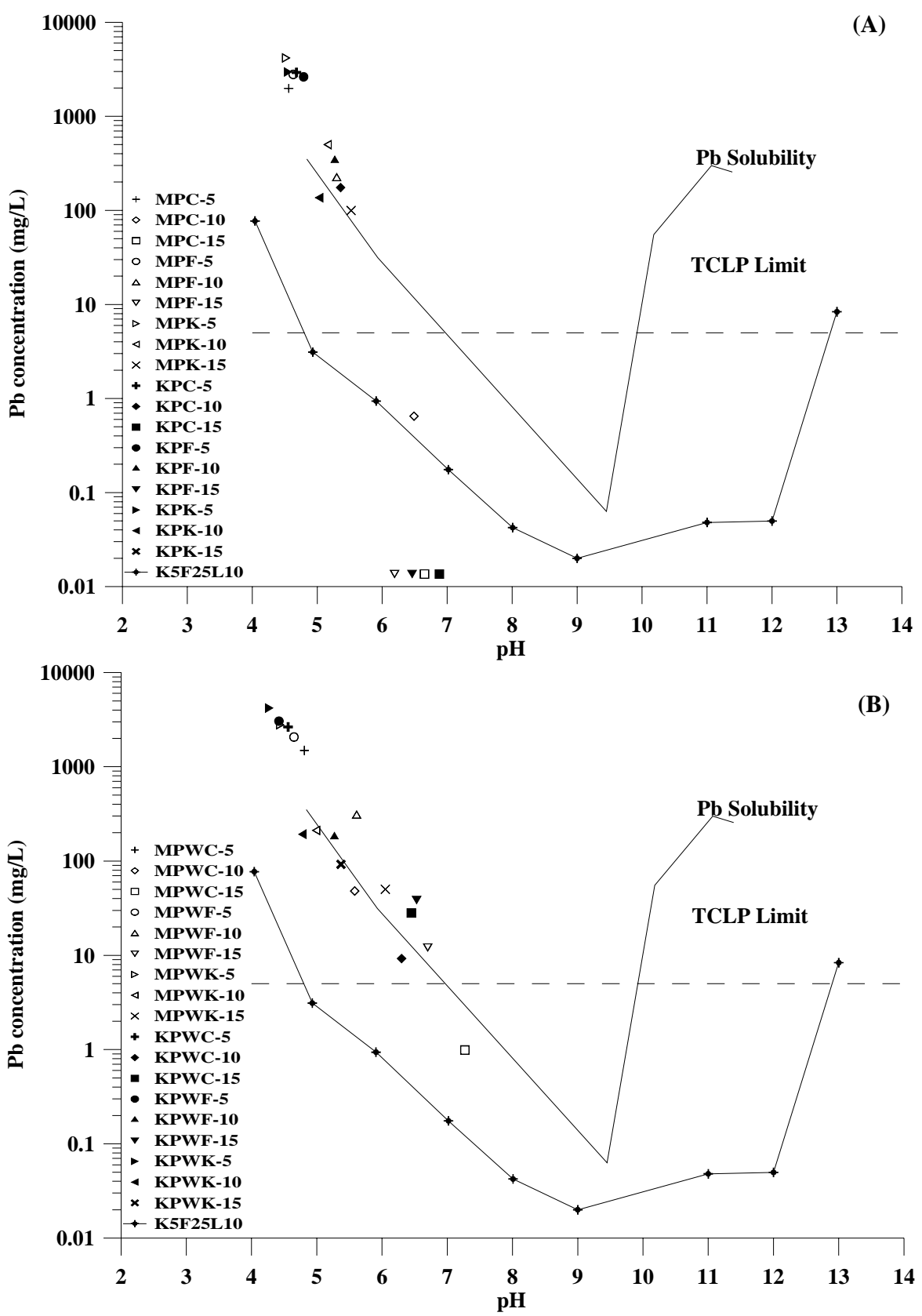

Figure 1. TCLP-Pb results for $\mathrm{Pb}(\mathrm{A})$ and $\mathrm{Pb}-\mathrm{W}(\mathrm{B})$ spiked media for 7 -day cured $S / S$ treatments 
After 1 day of curing only the $\mathrm{M}$ and $\mathrm{K}$ samples treated with $15 \% \mathrm{PC}$ and the $\mathrm{K}$ sample treated with $15 \%$ SFC were below the TCLP regulatory limit (data not shown). At 7 days, all $15 \%$ dosing levels produced $\mathrm{Pb}$ concentrations at the IDL except for the MPK-15 treatment (Figure 1a; KPK-15 data compromised). At 28 days (Figure 2a), all Pb concentrations failed the TCLP leaching criteria, except for sample KPC-15 (samples MPC-10, -15 compromised). As expected, $\mathrm{PC}$ was much more efficient than $\mathrm{CKD}$ for immobilizing $\mathrm{Pb}$, but it is interesting to note that the SFC did not outperform PC even though it is silica-enriched. This may be due to the delayed performance enhancements of silica fume which are known to take effect beyond 28 days. SFC stabilized Pb in kaolinite more effectively than CKD. However, the reverse was true for the $\mathrm{M}$ soils. Even though the addition of CKD to Pb contaminated soils failed to meet the TCLP regulatory criteria, $\mathrm{Pb}$ was immobilized to significantly lower levels than the initial concentrations. Moreover, what we also must not lose sight of is that the CKD is much less expensive than both PC and SFC ( $3 x$ to $4 x$ cheaper), and the $15 \%$ CKD treatments routinely outperformed the $5 \%$ and $10 \%$ PC and SFC treatments.
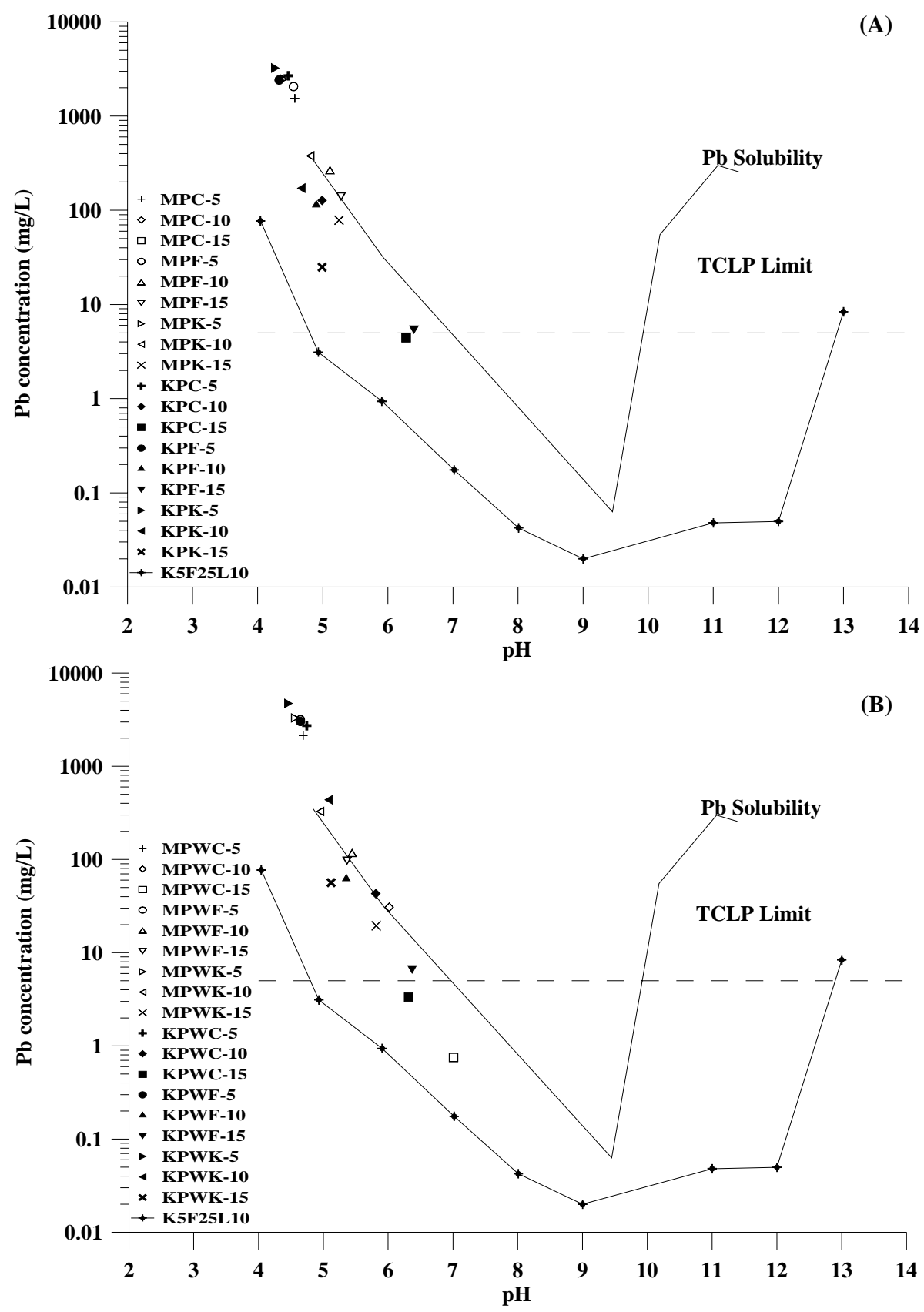

Figure 2. TCLP-Pb results for $\mathrm{Pb}(\mathrm{A})$ and $\mathrm{Pb}-\mathrm{W}(\mathrm{B})$ spiked media for 28-day cured $S / S$ treatments 
$\mathrm{Pb}$ immobilization was occasionally and frequently more pronounced in the $\mathrm{K}$ soils than the $\mathrm{M}$ soils at all curing times, opposite of what would be expected based on the acidity of the soils. However, these results are consistent with Dermatas and Meng (2003) who showed that at lower pHs (<9), greater immobilization tended to occur in the $K$ soils versus the $M$ soils. This trend was opposite of that observed by (Moon et al., 2006) who showed that $\mathrm{Pb}$ was immobilized to a greater degree in $\mathrm{M}$ than $\mathrm{K}$ upon quicklime treatment, very likely because the lime stabilized $\mathrm{M}$ soils produced $\mathrm{pH}$ s that were consistent with the $\mathrm{Pb}$ insolubility range.

\section{Pb-W Spiked Soil}

The leaching trends in the $\mathrm{Pb}-\mathrm{W}$ spiked system (Figures $1 \mathrm{~A}$ and $2 \mathrm{~B}$ ) were less straight forward than just the $\mathrm{Pb}$ spiked system. On average, the TCLP-Pb concentrations (28 days) were higher and comparable in the presence of $\mathrm{W}$ at 7- and 28-days curing, respectively, even though in some cases the non-W spiked systems were more acidic. PC and CKD were the best and worst performer for $\mathrm{Pb}$ stabilization in the presence of $\mathrm{W}$, respectively. With regard to $\mathrm{Pb}$ immobilization, the results for the $\mathrm{M}$ soil were consistently better than the $\mathrm{K}$ soil (except for the $15 \%$ SFC dose). This is most likely due to the $\mathrm{pH}$ effect on W concentrations, since the $\mathrm{M}$ treatments had a higher $\mathrm{pH}$ than the $\mathrm{K}$ treatments, indicating that $\mathrm{W}$ solubility was higher at elevated $\mathrm{pH}$.

The $\mathrm{M}$ soils were generally the more alkaline per pozzolan and dose than the $\mathrm{K}$ soils. While the dissolution of mineral $\mathrm{W}$ consumes alkalinity to produce $\mathrm{WO}_{4}{ }^{2-}$ (Pourbaix, 1974), which is the predominant tungsten species in solution above $\mathrm{pH} 6.2$ (in the tungsten-water system), the $\mathrm{Pb}-\mathrm{W}$ system tended to be somewhat more acidic at 7 days, but more alkaline at 28 days, though the corresponding $\mathrm{Pb}$ concentrations did not seem to follow a consistent pattern. The lower doses $(5 \%, 10 \%)$ appear to have performed somewhat better in the $\mathrm{Pb}-\mathrm{W}$ system at 7 days, but the $15 \%$ dose clustering was considerably worse. The lower $\mathrm{Pb}$ concentrations in the $\mathrm{Pb}-\mathrm{W}$ system at 7 days appeared to be linked to CKD and low PC/SFC doses in the M soils and $\mathrm{PC}$ in the $\mathrm{K}$ soil.

At 28 days, the $15 \%$ dose outperformed the 7 day data, whereas most of the $15 \%$ dose data shifted above the $\mathrm{Pb}$ solubility line. Compared to the $\mathrm{Pb}$ spiked system, the 28-day $\mathrm{pHs}$ in the $\mathrm{Pb}-\mathrm{W}$ system were generally more alkaline, but the $\mathrm{Pb}$ concentrations did not follow $\mathrm{a}$ consistent pattern other than the lower $\mathrm{Pb}$ concentrations in the $\mathrm{Pb}-\mathrm{W}$ system seemed to be associated with the higher CKD and SFC pozzolan doses for the M soils, and PC for the K soils, respectively.

The $\mathrm{W}$ concentrations in TCLP leachate in all of samples were less than 0.25 and $0.1 \mathrm{mg} \mathrm{l}^{-1}$ at 7 and 28-days, respectively, and were typically slightly lower in the K soils. Soluble $\mathrm{W}$ concentrations even at this low level were positively correlated with increasing $\mathrm{pH}$ (increasing pozzolan buffering capacity and dose).

\subsection{SPLP vs. $\mathrm{pH}$ solubility trends}

The SPLP-Pb results for the 28-day cured samples for $\mathrm{Pb}$ and $\mathrm{Pb}-\mathrm{W}$ spiked soils are shown in Figure 3 along with the SPLP-Pb regulatory limit $\left(0.015 \mathrm{mg} \mathrm{l}^{-1}\right)$ for reference purposes. Non-detects were plotted as the instrument detection limit (IDL) of $0.013 \mathrm{mg} \mathrm{I}^{-1}$ and compromised and/or incomplete data were not plotted.

\section{Pb Spiked Soil}

The most effective stabilizing agent on the SPLP-Pb leachability was the CKD, which routinely showed the lowest concentrations for each soil type. PC consistently and CKD routinely performed better in the $\mathrm{K}$ soil but the SFC results were opposite (Figure 3A). Five treatments remained below at the IDL: MPF-5, KPF-5, MPK-5, KPK-5 and KPC-5, indicating that the $5 \%$ dose provided sufficient alkalinity to both soils to minimize $\mathrm{Pb}$ leaching. Overall greater immobilization appeared to occur in the $\mathrm{K}$ soil. The $15 \%$ dosing level produced among the worst results primary because they were associated with the highest $\mathrm{pH}$. The remaining samples were above the SPLP limit. 
Pb-W Spiked Soil

With $\mathrm{W}$ present in the system, CKD performed the best followed by PC and SFC. Pb immobilization seemed to be more favored in the $M$ soils with the lower pozzolan doses performing among the best. The treatments MPWK-5, MPWK-10, MPWK-15, MPWF-5 and KPWC-10 were below the IDL after 28-days (Figure $3 \mathrm{~A}$ ). In the W-spiked soils systems, pH appeared to fluctuate the most in the low PC dose treatments, showing the greatest increases in the $\mathrm{M}$ soils and greatest reductions in the $\mathrm{K}$ soils. The SFC treated soils generally resulted in the highest $\mathrm{pHs}$. The highest $\mathrm{Pb}$ leachability was observed under the most alkaline conditions. On average, the $\mathrm{W}$ spiked samples did not lead to greater $\mathrm{Pb}$ leaching. This can most likely be attributed to the fact that the $\mathrm{W}$ had only a minimal effect on the $\mathrm{pH}$ of the SPLP extractions.
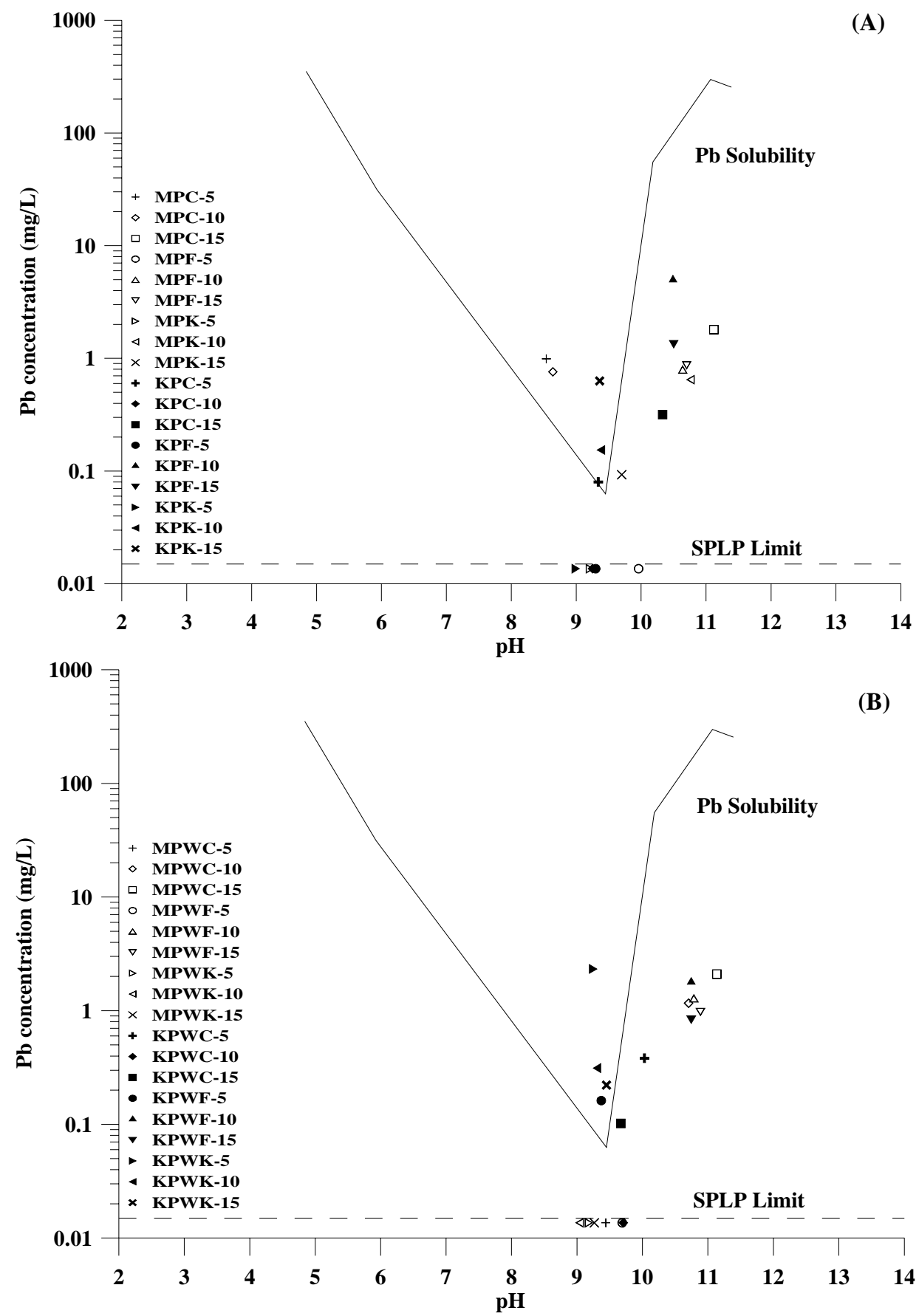

Figure 3. SPLP-Pb results for $\mathrm{Pb}(\mathrm{A})$ and $\mathrm{Pb}-\mathrm{W}(\mathrm{B})$ spiked media for 28-day cured $\mathrm{S} / \mathrm{S}$ treatments 
The corresponding SPLP-W concentrations were all below $1 \mathrm{mg} \mathrm{I}^{-1}$ except for three samples MPWC-15 (1.23 mg l-1), KPWC-15 $\left(1.04 \mathrm{mg} \mathrm{l}^{-1}\right)$ and KPWF-15 $\left(3.96 \mathrm{mg} \mathrm{I}^{-1}\right)$. Many samples were below $0.5 \mathrm{mg} \mathrm{l}^{-1}$. The KPWF-15 sample result appears to be an outlier as the KPWF-10 sample produced a SPLP-W concentration of $0.51 \mathrm{mg} \mathrm{I}^{-1}$ for the same $\mathrm{pH}$. W immobilization appeared to be favored the $\mathrm{M}$ soils, which were generally characterized by higher $\mathrm{pHs}$ except for the CKD series.

\subsection{XRD results for stabilized soils}

Select XRPD patterns (after background removal) for the 28-day cured samples MPWC, KPWC and KPWK at the $15 \%$ dosing level are presented to illustrate the $\mathrm{Pb}$ and $\mathrm{W}$ immobilization mechanisms, respectively, in Fig. 4A to 4C. In each case, mineral W, with its primary peak of $40.266^{\circ}(2 \theta)$, was clearly recognizable in all diffractograms indicating that the W powder was not fully solubilized or reacted with the 30-day mellowing period and 28-day curing timeframe.

The key differences between $\mathrm{Pb}$ speciation in the diffractograms are that lead silicate $\left(\mathrm{Pb}_{4} \mathrm{SiO}_{6}\right)$, stolzite $\left(\mathrm{Pb}\left(\mathrm{WO}_{4}\right)\right)$ and cerussite $\left(\mathrm{PbCO}_{3}\right)$ were detected in the MPWC-15 sample (Fig. 4A). The TCLP and SPLP pHs of the MPWC samples (7.01 and 11.14, respectively) were the highest of the samples shown in Figure 4. Accordingly, the greater $\mathrm{pH}$ buffering of $15 \% \mathrm{PC}$ in the $\mathrm{M}$ soil contributed to the formation of these minerals and thus greater $\mathrm{Pb}$ immobilization (under TCLP conditions). W appeared in its mineral form (W) and stolzite which has a $\mathrm{K}_{\mathrm{sp}}$ of $10^{-6.35}$ (Speight, 2004).

The speciation of $\mathrm{Pb}$ and $\mathrm{W}$ in the $\mathrm{K}$ soils was somewhat different and is likely attributed to differences in mineralogy and acidity. Lead tungsten oxide $\left(\mathrm{Pb}_{0.29} \mathrm{WO}_{3}\right)$ was detected instead of stolzite in the MPWC-15 sample whereas the KPWK-15 sample contained stolzite (trace), cerussite and hydrocerussite $\left(\mathrm{Pb}_{3}\left(\mathrm{CO}_{3}\right)_{2}(\mathrm{OH})_{2}\right)$ as the predominant lead species, and tungsten silicide $\left(\mathrm{WSi}_{2}\right)$.

Overall, the formation of stolzite, lead tungsten oxide, lead silicates, cerussite and hydrocerussite were found likely to be responsible for $\mathrm{Pb}$ immobilization in both $\mathrm{K}$ and $\mathrm{M}$ soils. The progression in the XRPD trends shown in Figs. 4A to $\mathrm{C}$ can be summarized as follows. The greater $\mathrm{Pb}$ leaching of the KPWK-15 treatment is attributed to the absence of lead silicates versus lead carbonates, whereas the main difference between KPWC-15 (Fig. 4B) and the MPWC-15 treatment (Fig 4A) is the acidity imparted by the kaolinite which creates, in part, a condition that allows for the formation of lead tungsten oxide.

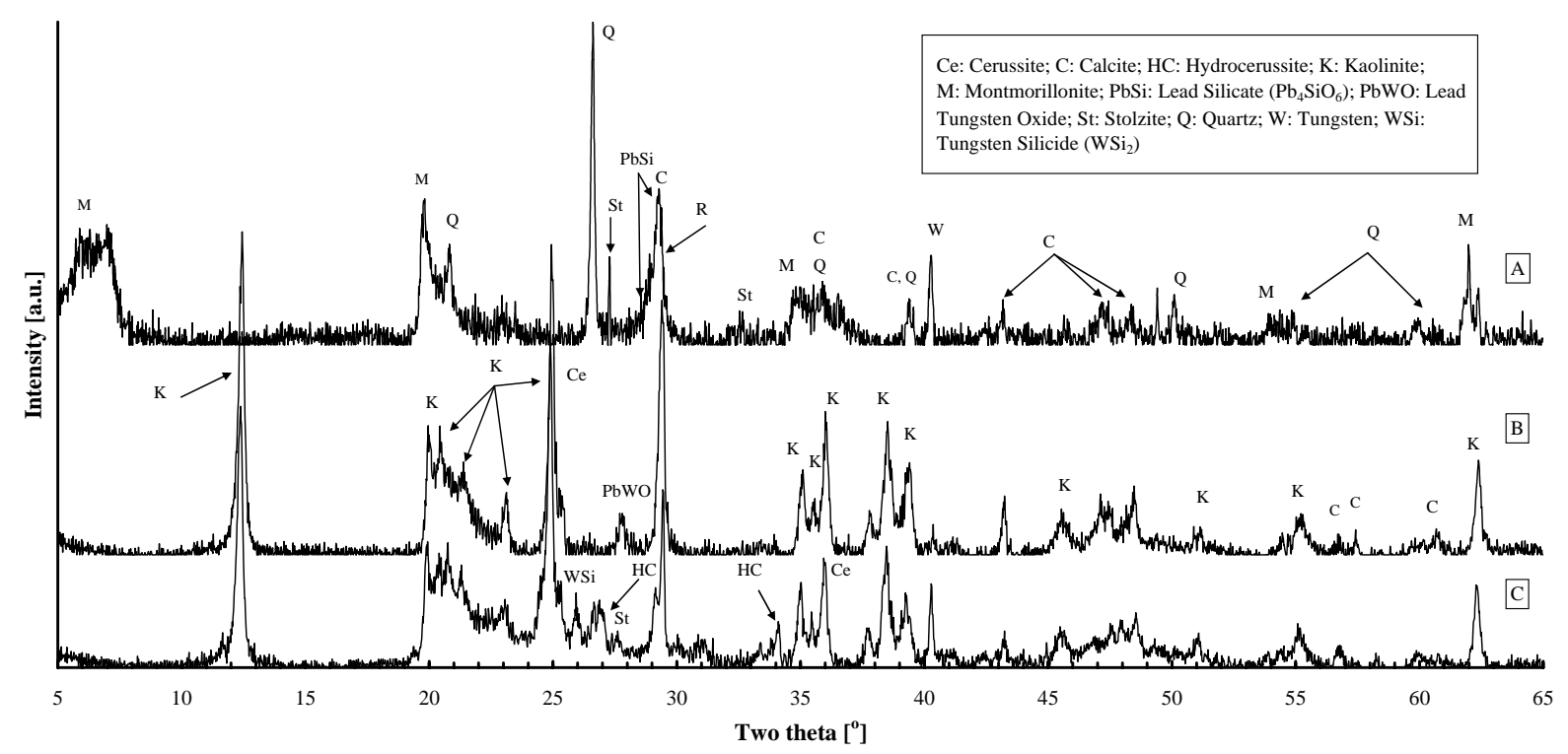

Figure 4. Diffractograms for 28-day cured samples MPWC-15 (A), KPWC-15 (B) and KPWK-15 (C) 
Lead silicates were previously reported by Moon et al. (2006) as being responsible for $\mathrm{Pb}$ immobilization upon quicklime treatment in $\mathrm{M}$ soils. Here, however, the formation of lead silicate $\left(\mathrm{Pb}_{4} \mathrm{SiO}_{6}\right)$ and stolzite $\left(\mathrm{PbWO}_{4}\right)$ appear to be the main compound associated with immobilizing $\mathrm{Pb}$, providing the lowest leaching level sunder TCLP conditions. The formation of cerussite and hydrocerussite were observed in the presence of $\mathrm{K}$, mainly due to its high calcite content. However, lead carbonates were not as effective as the $\mathrm{CSH}$, lead silicates and $\mathrm{PbWO}_{4}$ compounds for immobilizing $\mathrm{Pb}$. This would also explain the $\mathrm{pH}$ dependant leaching traits exhibited by these three treatments in the TCLP vs. $\mathrm{pH}$.

\section{CONCLUSIONS}

In this study, solidification/stabilization ( $\mathrm{S} / \mathrm{S}$ ) of $\mathrm{Pb}$ and $\mathrm{W}$ contaminated media using Type I/II Portland cement (PC), silica fume cement (SFC) and cement kiln dust (CKD) was conducted. The most effective stabilizing agent on the $\mathrm{Pb}$ and $\mathrm{W}$ leachability was $\mathrm{PC}$, with the TCLP-Pb concentrations satisfying the TCLP regulatory limit of $5 \mathrm{mg} \mathrm{I}^{-1}$ at $15 \%$ PC after 1 day. In other words, $15 \% \mathrm{PC}$ demonstrated the ability to immobilize $\mathrm{Pb}$ when the soil contained $\mathrm{Pb}$ and $\mathrm{W}$ concentrations up to $100,000 \mathrm{mg} \mathrm{kg}^{-1}$ and $10,000 \mathrm{mg} \mathrm{kg}^{-1}$, respectively, or theoretically $10 \%$ $\mathrm{Pb}$ and $1 \% \mathrm{~W}$ (the initial spiking concentrations).

Although the addition of CKD to Pb-contaminated soils failed to meet the TCLP regulatory criteria, $\mathrm{Pb}$ was immobilized to significantly lower levels than the initial concentrations. However, from a cost perspective, the comparison of the treatments at the $5 \%$ and $10 \%$ PC and SFC dosing rates to 15\% CKD shows that 15\% CKD would be the better choice for large scale treatment if bulking is not an issue. The XRPD results showed that lead silicate $\left(\mathrm{Pb}_{4} \mathrm{SiO}_{6}\right)$ and stolzite $\left(\mathrm{PbWO}_{4}\right)$ and lead tungsten oxide $\left(\mathrm{Pb}_{0.29} \mathrm{WO}_{3}\right)$ were detected in treatments providing the lowest TCLP-Pb results. As such, these minerals appear to be those most closely linked to $\mathrm{Pb}$ immobilization.

The $\mathrm{W}$ concentrations in TCLP leachate were less than $1 \mathrm{mg} \mathrm{l}^{-1}$ in all of the samples. This may due be to the low solubility of $\mathrm{W}$ at low $\mathrm{pH}$ conditions, the $\mathrm{S} / \mathrm{S}$ process or a combination of the two. The leachability of both $\mathrm{Pb}$ and $\mathrm{W}$ in all of the TCLP samples was dependent on the $\mathrm{pH}$ of the treatments.

The most effective stabilizing agent on the SPLP-Pb leachability was CKD, consistently demonstrating the lowest concentrations for each soil type. PC and SFC exhibit similar performance depending on the particular sample (not consistent with soil type, dosage, and curing time). For the SPLP-Pb-W spiked media, with regard to $\mathrm{Pb}$ immobilization, the effectiveness of the stabilizing agents followed the same order as that of the SPLP-Pb data. Again, CKD was the best performer (due to $\mathrm{pH}$ control in the 7 to 11 range), consistently showing the lowest concentrations for each soil type. PC and SFC treatments exhibited similar performance. The $\mathrm{W}$ concentrations in SPLP leachate were very low in most of samples.

\section{ACKNOWLEDGMENTS}

This work was funded under U.S. Army ARDEC Contract Number W15QKN-05-D-0011, Task orders No. 5 and 11. The PC, SFC and CKD were provided by Mr. Jeff Fair of LaFarge North America (Coopersburg, PA). All experiments were performed at the W.M. Keck Geoenvironmental Laboratory at Stevens.

\section{REFERENCES}

Air Force Research Laboratory, Munitions, Directorate (AFRL) (2003) Environmental Effects of Tungsten and Tantalum Alloys, Report No. AFRL-MN-EG-TR-2000-7017.

Baghdadi Z.A. (1990) Utilization of kiln dust in clay stabilization, Eng. Sci., Jeddah, Scientific Publication Center, King Addul Aziz University.

Betancur J. (2007) A novel approach for the remediation of mixed lead and tungsten contaminated firing rang soils, M.Sc. Thesis, Department of Civil, Ocean and Environmental Engineering, Stevens Institute of Technology, Hoboken, NJ, December.

Cao X., Ma L.Q., Chen M., Hardison D.W., and Harris W.G. (2003) Lead transformation and distribution in the soils of shooting ranges in Florida, USA, Sci. Total. Environ., 307, 179-189. 
Chipera S. and Bish D. (2001) Baseline studies of the Clay Mineral Society source clays: Powder x-ray diffraction analyses, Clay and Clay Minerals., 49(5), 398-409.

Chrysochoou M., Dermatas D. and Grubb D.G. (2007) Phosphate application to firing range soils for $\mathrm{Pb}$ immobilization: The unclear role of phosphate, Journal of Hazardous Materials, 144(1-2), 1-14.

Conner J.R. (1990) Chemical fixation and solidification of hazard wastes, Van Nostrand Reinhold, New York.

Department of the Interior, Fish and Wildlife Service (DOI) (1999). Migratory Bird Hunting; Final Approval of Tungsten-Iron and Tungsten-Polymer Shots and Temporary Approval of Tungstenmatrix and tin Shots as nontoxic for Hunting Waterfowl and Coots, Proposed Rules, Federal Register, 64(116), 32751-32756.

Dermatas D. and Meng X. (1996) Stabilization/solidification (s/s) of heavy metal contaminated soils by means of a quicklime-based treatment approach, Stabilization and Solidification of Hazardous, Radioactive, and Mixed Wastes, ASTM STP 1240, vol. 1. American Society for Testing and Materials, Philadelphia, pp. 449- 513.

Dermatas D. and Meng X. (2003) Utilization of fly ash for stabilization/solidification of heavy metal contaminated soils, Eng. Geol., 70, 377-394.

Dermatas D., Braida W., Christodoulatos C., Strigul N., Panikov N., Los M. and Larson S. (2004a) Solubility, sorption and soil respiration effects of tungsten and tungsten alloys, Environmental Forensics, 5, 5-13.

Dermatas D., Dutko P., Menounou N., Dadachov M., Arienti P., Shen G. and Tsaneva V. (2004b) Lead and copper contamination in small arms firing ranges, Global Nest: the Int. J., 6(2), 143150.

Dermatas D., Dadachov M., Dutko P., Menounou N., Arienti P. and Shen G. (2004c) Weathering of lead in Fort Irwin firing range soils, Global Nest: the Int. J., 6, 167-175.

Dermatas D., Moon D.H., Menounou N., Meng X. and Hires R. (2004d) An evaluation of arsenic release from monolithic solids using a modified semi-dynamic leaching test, J. Hazard. Mater., B116, 25-38.

Dermatas D., Menounou N., Dadachov M., Dutko P., Shen G., Xu X. and Tsaneva V. (2006) "Lead leacahbility in firing range soils, Environ. Eng. Sci., 23, 88-101.

Dyer T.D., Halliday J.E., and Dhir R.K. (1999) An investigation of the hydration chemistry of ternary blends containing cement kiln dust, J. Mater. Sci., 34(20), 4975-4983.

Grubb D.G., Chrysochoou M. and Smith C.J. Stabilized Dredged Material I: A parametric study, Journal of Geotechnical and Geoenvironmental Engineering (in press).

Inorganic Crystal Structure Database (ICSD) (2006) Fachinformationszentrum Karlsruhe, Germany.

International Centre for Diffraction Data (ICDD) (2002) Powder Diffraction File, PDF-2 Database Release.

Interstate Technology \& Regulatory Council (ITRC) (2003) Small Arms Firing Range Team. Technical/Regulatory Guidelines. Characterization and Remediation of Soils at Closed Small Arms Firing Ranges, Report No. SMART-1, January.

Jing C., Meng X. And Korfiatis G.P. (2004) Lead leachability in stabilized/solidified soil samples evaluated with different leaching tests, J. Hazard. Mater., B114, 101-110.

Koutsospyros A., Braida W., Christodoulatos C., Dermatas D. and Strigul N. (2006) A review of tungsten: from environmental obscurity to scrutiny, Journal of Hazardous Material, 136, 1-19.

Lassner E. and Schubert W.-D. (1999) Tungsten properties, chemistry, technology of the element, alloys, and chemical compounds, Kluwer Academic/Plenum Publishers, Boston.

MDI (Material's Data Inc.). (2005) Jade Version 7.1, California, U.S.A.

Miller G.A. and Azad S. (2000) Influence of soil type on stabilization with cement kiln dust, Construct Build Mater, 14(2), 89-97.

Moon D.H. and Dermatas D. (2006) An evaluation of lead leachability from stabilized/solidified soils under modified semi-dynamic leaching conditions, Eng. Geol., 85, 67-74.

Moon D.H., Dermatas D. and Grubb D.G. (2006) The effectiveness of quicklime-based stabilization/solidification on lead $(\mathrm{Pb})$ contaminated soils, In: Environmental Geotechnics (5th ICEG), Thomas H.R. (ed.), Thomas Telford Publishing, London, 1, 221-228.

Osseo-Asare K. (1982) Solution chemistry of tungsten leaching systems, Metallurgical Transactions $B$, 13B, 555-564. 
OSHA (US Occupational Safety and Health Organization) (1994) Tungsten and Cobalt in Workplace Atmospheres (ICP Analysis), Method No. ID-213, OSHA Salt Lake Technical Center, Salt Lake City, UT (www.osha.gov/dts/sltc/methods/inorganic/id213/id213.html).

Palomo A. and Palacios M. (2003) Alkali-activated cementitious materials: alternative matrices for the immobilization of hazardous wastes part II. stabilization of chromium and lead, Cement and Concrete Res, 33, 289-295.

Pourbaix M. (1974) Atlas of electrochemical equilibria in aqueous solutions, NACE Int., Ceblecor

Rietveld H.M. (1969) A profile refinement method for nuclear and magnetic structures, J. Appl. Crystal., 2, 65-71.

Sadiq M., Mian A.A., and Althagafi K.M. (1992) Inter-city comparison of metals in scalp hair collected after the Gulf War, J. Environ. Sci. Health Part A, 27, 1415-1431.

Sanitary Rules and Norms of Russian Federation. (1996). Moscow.

Shi C. and Spence R. (2004) Designing of cement-based formula for solidification/stabilization of hazardous, radioactive, and mixed wastes, Critical Reviews in Environmental Science and Technology, 34(4), 391-417.

Singh T.S., and Pant K.K. (2006) Solidification/stabilization of arsenic containing solid wastes using Portland cement, fly ash and polymeric materials, J. Hazard. Mater., B131, 29-36.

Solem-Tishmack J.K., McCarthy G.J., Docktor B., Eylands K.E., Thompson J.S. and Hassett D.J. (1995) High calcium coal combustion by-products: Engineering properties, ettringite formation and potential applications in solidification and stabilization of selenium and boron, Cement and Concrete Research, 25(3), 658-670.

Speight J.G., (2004) Lange's Handbook of Chemistry, $16^{\text {th }}$ Ed., McGraw Hill.

Sreekrishnavilasam A., Rahardja S., Kmetz R., and Santagata M. (2007) Soil treatment using fresh and landfilled cement kiln dust, Construction and Building Materials, 21 (2), 318-327.

State Russian Committee for Fishing (1999) Order \# 96, 28 April, Moscow.

Strigul N., Koutsospyros A., Arienti P., Christodoulatos C., Dermatas D. and Braida W. (2005) Effects of tungsten on environmental systems, Chemosphere, 61, 248-258.

U.S. Environmental Protection Agency (1992) Toxicity Characteristic Leaching Procedure, Method 1311, Washington D.C.

U.S. Environmental Protection Agency (1992) Synthetic Precipitate Leaching Procedure, Method 1312, Washington D.C.

USEPA (2005) Best management practices for lead at outdoor shooting ranges, EPA-902-B-01001, Revised, http://www.epa.gov/region2/waste/leadshot/

USGS (1998) International strategic mineral issues. Summary report-tungsten, USGS Survey Circular 930-O. US Department of Interior, Washington, DC.

USGS (2002) Lead in December 2001. Mineral industry surveys, USGS US Geological Survey Minerals Information Publications Services 984 National Center Reston, VA 20192.

Yukselen M.A., and Alpaslan B. (2001) Leaching of metals from soil contaminated by mining activities, J. Hazard. Mater., 87(1-3), 289-300.

Zaman M., Laguros J.G. and Sayah A. (1992) Soil stabilization using cement kiln dust, Proceedings 7th international conference on expansive soils, Dallas, TX, 347-351. 